\title{
Biochemical attributes of castor and tapioca leaves, the promising food plants of eri silkworm (Samia ricini Donovan)
}

\author{
J. Deuri ${ }^{1}$, P. K. Barua ${ }^{1}$, M. C. Sarmah ${ }^{2}$ and S. A. Ahmed ${ }^{2 *}$ \\ ${ }^{1}$ Department of Botany, University of Science and Technology, Meghalaya, Ri-Bhoi, India. \\ ${ }^{2}$ Central Muga Eri Research and Training Institute, Central Silk Board, Jorhat-785700, India.
}

Accepted 25 April, 2017

\begin{abstract}
Ericulture has emerged as the promising livelihood venture in Bodoland Territorial Council of Assam employing about 50610 farm families in 1573 villages with production level of about 369 metric tons of eri raw silk. The biochemical analysis of two promising food plants of eri silkworm viz., castor (Ricinus communis L.) and tapioca (Manihot esculenta) revealed the superiority of castor food plants with higher crude protein (17.43\%), lipid (10.95\%) and crude fibre (5.53\%). The tapioca may be utilized as promising food plants with its balanced primary metabolites such as crude protein (10.83\%), carbohydrate (32.14\%) and sugar $(2.92 \%)$ as well as its lower content of phenol $(9.82 \%)$ as compared to castor. However, the selection of location specific and low $\mathrm{HCN}$ content tapioca will make the ericulture more sustainable and cost effective.
\end{abstract}

Keywords: Ericulture, castor, tapioca, biochemical constituents.

*Corresponding author. E-mail: saahmed31@gmail.com.

\section{INTRODUCTION}

Eri silkworm (Samia ricini Donovan) is exclusive prerogative of North Eastern States of India and of late introduced to other parts of India. Eri silkworm being hardy and tolerant to diseases, its productivity per acreage is higher compared to other silkworm varieties. The culture is eco-friendly and is a low investment enterprise. Unlike other silks, only spun silk can be produced from eri cocoons and hence, boil of loss during its spinning is very less. As on date, a number of diversified fabrics have been produced from eri silk taking advantage of its strong affinity to dyes and blending properties with other natural and synthetic yarns. The different recipes of eri silk pupa are having huge demand in the tribal dominated states of N.E. Region (Singh and Ahmed, 2017). Castor seeds contain $50 \%$ oil; it can be used for manufacturing of soap, medicine, lubricants, detergent etc. Tapioca tuber contains 25 to $30 \%$ starch in dry weight basis. Fresh tubers are used for production of Ethanol. Brazil has taken initiative for production of alcohol and ethanol. The hill regions of North Eastern region of India have ample scope for expansion of tapioca cultivation not only as a source for supplementary diet for the people but also increasing the quantum of leaf for eri cocoon productions.

The BTAD enjoys the unique distinction of producing all the three varieties of commercially exploited natural silks - eri, muga and mulberry. The Bodo belt is the largest producer of eri raw silk in Assam after Karbi Along. A total land area of 2,895 hectares is covered under muga, eri and mulberry silkworm food plant in the BTAD with 51,195 families being directly involved in sericulture with around 356 metric tonnes of eri raw silk was produced in the districts governed by the Bodo Territorial Council (BTC), which is about 30 to $40 \%$ of the total raw silk production of Assam. The eri silk is primarily reared on Castor, Kesseru, Tapioca and other food plants of which Castor and Tapioca dominates in ericulture of BTC. The present study has been conducted to assess 
the nutritional status of castor and tapioca leaves vis-àvis rearing performance of eri silkworm feeding on this food plant.

\section{MATERIALS AND METHODS}

\section{Study area}

The study was conducted in Bodo Territorial Council, Assam, India. The global location of the area is between $26.4^{\circ} \mathrm{N}$ and $90.27^{\circ} \mathrm{E}$, covering a land area of about 8,795 square kilometers, with an estimated population of 3.10 e million people.

\section{Preparation of leaf samples}

Leaf samples of castor and tapioca were collected separately from each host plants during December to February, May to June, July to August and October to November during the year 2012 and 2013. The leaves were properly cleaned and then dried in hot air oven at a temperature ranging between 80 and $90^{\circ} \mathrm{C}$ for several hours till dried completely. The dried leaves were ground in an electric grinder (Make: BAJAJ Mixer grinder Gx7) to make fine powder. The powdered leaf samples were kept separately in polypropylene containers which were subsequently used for analysis.

\section{Analytical techniques}

The following standard techniques were employed to assess the biochemical status of leaf samples:

i) Total soluble protein was determined by the method of Lowry et al. (1951).

ii) Total carbohydrates and total soluble sugars were determined by following Anthrone method (Sadasivam and Manickam, 2005).

iii) The crude fibre content was determined by the method of AOAC (1965, 1970).

iv) Moisture content was estimated by taking the difference between the fresh and dry weights and expressed in percentage on fresh weight basis (A.O.A.C., 1970).

v) The method described by Price and Butler (1977) was employed to determine total phenol contents.

vi) Tannins were estimated following the Folin-Dennis method (Schanderl, 1970).

vii) Sadasivam and Manickam (2005) method was used to determine Free amino acid and lipid.

The statistical analysis was done using SPSS tool.

\section{RESULTS AND DISCUSSION}

\section{Eri silk productivity}

The present study revealed that the higher cocoon shell yield production in castor fed eri silkworm as compared to other food plants. The details of yield per 100 disease free layings (dfls) of eri silkworm fed on castor (Ricinus communis), kesseru (Heteropanax fragrans) and tapioca (Manihot esculanta) during Autumn, 2012-13 conducted in the four districts of BTC viz, Kokrajhar, Baksa, Chirang and Udalguri are presented in Table 1.

\section{Biochemical analysis}

The leaf biochemical compositions were varied significantly between castor and tapioca leaves. However, the seasonal variations were not found significant in case of food plants. These may be due to lesser variations in soil and climatic conditions among the four selected districts of the BTC area. Significantly higher crude protein was recorded in castor leaves than tapioca. Castor leaves showed highest crude protein in spring season while the lowest crude protein was obtained from tapioca leaves in winter season (Tables 2 and 3). Among the four seasons, spring showed highest crude protein percent followed by summer, autumn and winter.

The lipid content of tapioca leaves was significantly lower than castor leaves. Castor leaves showed highest lipid content in autumn season while tapioca leaves showed lowest lipid content in spring. Lower the amount of crude fibre, better is the food plant. The crude fibre was lowest in spring season and highest in autumn. Between castor and tapioca, the leaves of tapioca showed significantly lower crude fibre.

Moisture content was higher in tapioca leaves than castor, although the difference was non-significant. Spring represented highest moisture in the leaves whereas it was recorded lowest in winter. The sugar content was highest in autumn season; however, there was no significant difference among other seasons. The sugar content was significantly higher in castor leaves than tapioca leaves.

Comparable results were obtained for total carbohydrate content between the leaves of castor and tapioca; although, it was found a little higher in tapioca than castor. Among the various seasons, the carbohydrate content was lowest in summer. Higher phenol was obtained in castor leaves than tapioca leaves. Lowest phenol content was obtained in autumn season. There were no significant differences among the other seasons. Significantly lower amount of tannin content was obtained in castor leaves as compared to the tapioca leaves. Autumn showed lowest and spring showed the highest tannin content in both castor and tapioca leaves. Free Amino acid content of castor leaves was higher than the tapioca leaves. Winter leaves showed highest amount of free amino acid as compared to other seasons.

The higher nutritional values and lower anti-nutrient contents (like tannin) in castor could be attributed to the superior economic traits including cocoon yield and silk percentage and found most suitable for ericulture whereas in tapioca the economic traits were recorded least which could be due to poor nutrient contents in leaf. It is also supported by earlier findings (Bongale et al., 
Table 1. Comparative eri silk and its bye products per $100 \mathrm{dfls}$ of eri silkworm.

\begin{tabular}{lccc}
\hline \multirow{2}{*}{ Particulars } & \multicolumn{3}{c}{ Host plants } \\
\cline { 2 - 4 } & Castor & Kesseru & Tapioca \\
\hline Cocoon shell $(\mathrm{kg})$ & 9.4 & 7.6 & 6.1 \\
Pupa $(\mathrm{kg})$ & 40 & 32.1 & 25.5 \\
Excreta $(\mathrm{kg})$ & 200 & 159.8 & 127.8 \\
Litter $(\mathrm{kg})$ & 283.3 & 226.8 & 181.4 \\
\hline
\end{tabular}

Table 2. Chemical constituents in leaf biomass of castor during different seasons.

\begin{tabular}{|c|c|c|c|c|c|c|c|c|c|}
\hline Seasons & $\begin{array}{c}\text { Crude protein } \\
(\%)\end{array}$ & Lipid (\%) & $\begin{array}{c}\text { Crude fibre } \\
(\%)\end{array}$ & Moisture (\%) & Sugar (\%) & $\begin{array}{c}\text { Carbohydrate } \\
(\%)\end{array}$ & $\begin{array}{c}\text { Phenol } \\
(\%)\end{array}$ & Tannin (\%) & $\begin{array}{l}\text { Free amino acid } \\
(\mathrm{mg} / 100 \mathrm{~g})\end{array}$ \\
\hline Summer (Jul-Aug) & $17.88(0.96)$ & $11.11(1.53)$ & $5.02(0.57)$ & $82.49(4.14)$ & $4.47(0.07)$ & $26.58(1.07)$ & $20.34(0.91)$ & $1.53(0.08)$ & $0.64(0.08)$ \\
\hline Autumn (Oct-Nov) & $17.24(1.31)$ & $11.50(0.65)$ & $6.38(0.36)$ & 80.03 (1.57) & $5.23(0.02)$ & $27.64(0.91)$ & $15.67(0.62)$ & $1.00(0.24)$ & $0.83(0.03)$ \\
\hline Winter (Dec-Feb) & 15.59 (1.92) & $11.07(0.59)$ & $6.33(0.19)$ & 72.83 (3.93) & $4.83(0.41)$ & $27.78(0.44)$ & $20.18(0.62)$ & $1.56(0.13)$ & $0.98(0.04)$ \\
\hline Spring (May-Jun) & $18.99(0.89)$ & $10.12(0.20)$ & $4.38(0.10)$ & $86.60(2.90)$ & $4.40(0.08)$ & $29.69(0.37)$ & $20.56(0.22)$ & $1.74(0.29)$ & $0.63(0.06)$ \\
\hline Mean & 17.43 & 10.95 & 5.53 & 80.49 & 4.73 & 27.92 & 19.19 & 1.46 & 0.77 \\
\hline
\end{tabular}

Data in the parenthesis are standard deviation.

Table 3. Chemical constituents in leaf biomass of tapioca during different seasons.

\begin{tabular}{|c|c|c|c|c|c|c|c|c|c|}
\hline Seasons & Crude protein (\%) & $\begin{array}{c}\text { Lipid } \\
(\%) \\
\end{array}$ & $\begin{array}{c}\text { Crude fibre } \\
(\%)\end{array}$ & $\begin{array}{c}\text { Moisture } \\
(\%) \\
\end{array}$ & Sugar (\%) & $\begin{array}{c}\text { Carbohydrate } \\
(\%)\end{array}$ & Phenol (\%) & Tannin (\%) & $\begin{array}{c}\text { Free amino } \\
\text { acid }(\mathrm{mg} / 100 \mathrm{~g})\end{array}$ \\
\hline Summer (Jul-Aug) & $10.73(1.50)$ & $0.19(0.01)$ & $1.81(0.12)$ & $88.05(4.13)$ & $2.90(0.02)$ & $28.96(1.25)$ & $9.77(0.49)$ & $14.03(0.05)$ & $0.19(0.01)$ \\
\hline Autumn (Oct-Nov) & $10.33(0.86)$ & $0.26(0.01)$ & $2.07(0.07)$ & $84.28(3.87)$ & $3.09(0.11)$ & $32.47(0.61)$ & $9.20(0.09)$ & $14.01(0.21)$ & $0.18(0.01)$ \\
\hline Winter (Dec-Feb) & $9.37(0.90)$ & $0.25(0.01)$ & $1.78(0.02)$ & 76.45 (4.99) & $2.86(0.05)$ & $34.01(0.79)$ & $10.10(0.03)$ & $14.72(0.18)$ & $0.20(0.01)$ \\
\hline Spring (May-Jun) & $12.90(0.30)$ & $0.17(0.01)$ & $1.60(0.01)$ & $89.57(1.26)$ & $2.81(0.12)$ & $33.12(1.10)$ & $10.23(0.04)$ & $15.15(0.13)$ & $0.19(0.01)$ \\
\hline Mean & 10.83 & 0.22 & 1.81 & 84.59 & 2.92 & 32.14 & 9.82 & 14.48 & 0.19 \\
\hline
\end{tabular}

Data in the parenthesis are standard deviation.

1991). The relationship between quality parameters of castor leaves exhibited positive correlation with all economic traits except that of larval period which decreased with increase in nutritional content of leaves. Similar results were also observed in case of tapioca leaves. Sarmah et al. (2011) opined that ERR of eri silkworm was influenced by biochemical compositions of leaves.
The weight of larvae and cocoons were significantly influenced by nitrogen and crude protein content of the foliage. This is supported by the present report. The anti-nutrients like, tannin, 
phenol etc. had negative impact on the economic traits of eri silkworm. The increased level of tannin could cause reduced intake of leaves and digestibility in silkworm as reported by earlier workers (Reed et al., 1982). High phenol content affects on feeding during larval stage as reported by Rao et al. (2009) and Anjani et al. (2010).

In the present study, the castor leaves were found superior than the tapioca leaves. However, in some case of some nutrients, there is no significant difference between castor and tapioca leaves and also the cocoon yield and silk percentage, suggesting that tapioca is also a suitable food plant for eri silkworms.

\section{REFERENCES}

Anjani K, Pallavi M, Babu SNS, 2010. Biochemical basis of resistance to leaf miner in castor (Ricinus communis L.). Ind Crops Prod, 31: 192-196.

AOAC, 1965. Official methods of analysis $9^{\text {th }}$ Edn. Association of official Analytical Chemist, Washington D.C.

AOAC, 1970. Official methods of analysis $10^{\text {th }} \mathrm{Edn}$. Association of official Analytical Chemist, Washington D.C.

Bongale VD, Chaluvachari, Rao NBV, 1991. Mulberry leaf quality evolution and its importance. Indian Silk, 29(11): 51-53.

Lowry OH, Rosebrough NJ, Farr AL, Randall RJ, 1951. Protein measurement with folin phenol reagent. J Biol Chem, 193: 265-275.

Price ML, Butler LG, 1977. Rapid visual estimation and spectrophotometric determination of tannin content of sorghum grain. J Agric Food Chem, 25(6): 1268-1273.

Rao PVR, Shankar VG, Reddy AV, 2009. Variability studies in castor (Ricinus communis L.). Res Crops, 10: 696-698.

Reed JD, McDowell RE, Van Soest PJ, Horvath PJ, 1982. Condensed tannin: A factor limiting to use of cassava foliage. J Sci Food Agric, 33: 21-31.

Sadasivam S, Manickam A, 2005. Biochemical methods. New Age International Limited Publisher, New Delhi.

Sarmah MC, Chutia M, Neog K, Das R, Rajkhowa G, Gogoi SN, 2011. Evaluation of promising castor genotype in terms of agronomical and yield attributing traits, biochemical properties and rearing performance of eri silkworm, Samia ricini (Donovan). Industrial Crop Prod, 34: 1439-1446.

Schanderl SH, 1970. Methods in Food Analysis. Academic Press, New York, Pp. 709.

Singh BK, Ahmed SA, 2017. Ericulture. In: Industrial Entomology, Omkar (Ed.) Springer, 340-370.
Citation: Deuri J, Barua PK, Sarmah MC, Ahmed SA, 2017. Biochemical attributes of castor and tapioca leaves, the promising food plants of eri silkworm (Samia ricini Donovan). Int J Ecol Ecosolution, 4(4): 1-4. 